sciendo Порівняльна професійна педагогіка 9(4)/2019 Comparative Professional Pedagogy 9(4)/2019

DOI: $10.2478 /$ rpp-2019-0037

Undergraduate Student (P), USMAN HASSAN

Department of Bioengineering, Integral University, Lucknow, Uttar Pradesh, India. Address: Integral University, Kursi Road, Lucknow Uttar Pradesh, India. 226024 E-mail: hassanusman391@gmail.com

Undergraduate Student (P), TALAT ZAHRA

Department of Electronics \& Communication, Integral University, Lucknow, Uttar Pradesh, India. Address: Integral University, Kursi Road, Lucknow Uttar Pradesh, India. 226024 E-mail: talatzahra1698@gmail.com

Assistant Professor, SHRISH BAJPAI Electronics \& Communication Engineering, Department, Integral University, Lucknow, Uttar Pradesh, India. Address: Integral University, Kursi Road, Lucknow Uttar Pradesh, India. 226024 E-mail: shrishbajpai@gmail.com

\title{
BIOMEDICAL ENGINEERING EDUCATION IN INDIA
}

\section{ABSTRACT}

In the industrialized nation, almost every facet of our lives is permeated by technological innovation at an accelerated pace. This is especially true in the areas related to health and medicine, which has further led to the evolution of a health care system that is technologically related and capable of providing a wide range of effective therapeutic and diagnostic treatments. The application of the principles and problem-solving techniques of engineering, biology and medicine is Biomedical engineering. Biomedical engineering focuses on the advancements to improve human health at all possible levels. Biomedical engineering has emerged as a new area of research combining biology and medicine with technology, providing new designs and concepts of medical instrumentation for the diagnosis, cure and prevention of various diseases. Biomedical engineering in the last three decades has sustained growth in human resources along with the emergence of careers as graduates and postgraduates and apart from this research works, health care and technological development are some of its other aspects. The present paper will provide an insight into biomedical engineering and future scopes, specifically in India. Biomedical engineers use and apply knowledge of the modern biological principles in their designing process. A biomedical engineer can work in a wide variety of areas and disciplines. Apart from this, there are several opportunities in industries for innovations, designing and developing new techniques. In the last few years, biomedical engineering has emerged as a booming career as the area of work and research and the possibilities of innovations in this field are nearly endless. Thus, the future of biomedical engineering is tied to both the obstacles we face in the field of medical sciences and its advancements. Hence the use of the biomedical engineering method has become a necessity for human health, research and development.

Keywords: Biomedical Engineering, engineering education in India, technical education, medical education. 
sciendo Порівняльна професійна педагогіка 9(4)/2019 Comparative Professional Pedagogy 9(4)/2019

\section{АНОТАЦІЯ}

У промислових країнах технологічні інновачії швидкими темпами проникають у майже всі аспекти життя. Особливо ие стосується галузі охорони здоров'я та медицини, адже технології приводять до еволючї галузей, які $\epsilon$ високо технологічними та спроможними забезпечити широкий спектр ефективного терапевтичного та діагностичного лікування. Застосування принципів та методів вирішення проблем у інженерії, біології та медицині є прерогативою біомедичної інженерії, яка зосереджується на тому, аби покращити здоров'я людей усіма можливими шляхами. Освіта у галузі біомедичної інженерії з'явилася як нова галузь дослідження, що поєднує біологію та медицину з технологіями, забезпечуючи нові проекти та конщепти медичного інструментарію для діагностики, лікування та запобігання хворобам. За останні три десятиліття у біомедичній інженерії зайнято все більше прачюючих кадрів, здійснюється навчання студентів відповідних спеціальностей та аспірантів. Окрім досліджень, які проводяться у иій галузі, провідними аспектами є охорона здоров'я та технологічний розвиток. У статті охарактеризовано освіту у галузі біомедичної інженерії, окреслено ї̈ майбутні перспективи, особливо в Індії. 3'ясовано, щу біомедичні інженери використовують та застосовують знання сучасних біологічних принципів у прочесі проектування та конструювання. Біомедичні інженери можуть прачювати у різних галузях та спеціальностях. Окрім цьього, освіта у галузі біомедичної інженерії відкриває нові можливості для інновацій, проектування та розвитку нових технологій у промисловості. За останні кілька років освіта у галузі біомедичної інженерії стала прогресивною професією, галуззю знань та дослідження, і можливості інновацій у ній майже безмежні. Загалом, майбутнє освіти у галузі біомедичної інженерії тісно пов'язане як з проблемами у медичній галузі, так $i$ з ї̈ розвитком. Використання методів біомедичної інженерії стало необхідністю для забезпечення здоров'я людей, дослідження та розвитку.

Ключові слова: біомедична інженерія, освіта у галузі біомедичної інженерії в Індії, технічна освіта, медична освіта.

\section{INTRODUCTION}

There is a long history behind the practice of biomedical engineering. A leather and wood prosthetic toe found on a more than 1500 years old Egyptian mummy is one of the earliest examples. Before that, even simple crutches and walking sticks were a form of engineered assistive devices, and the first person to design a splint for a broken bone could be considered to have been an early biomedical engineer.

Biomedical engineering is an upcoming field, but before its origination here in India, ancient practices of Ayurveda to treat various diseases were quite common (Padmanabhan and Padmanabhan, 2019). In the $3^{\text {rd }}$ century BC, Charaka was one of the main contributors to Ayurveda which was a system of medicine and lifestyle in ancient India (Ovallath, \& Deepa, 2013). The contributions made by Charaka in the fields of physiology, etiology, and embryology have been highly recognized (Mukhopadhyay, 2016). Apart from this, the works and contributions of Sushruta, an ancient Indian physician, to the medical field are highly admired (Bath et al., 2019). The Sushruta Samhita is also one of the most important surviving ancient treatises on medicine and is also considered a foundational text of the Ayurveda (Gharge and Naik, 2019). These were some early practices in India 
sciendo Порівняльна професійна педагогіка 9(4)/2019 Comparative Professional Pedagogy 9(4)/2019

before the invention of the instrumentation techniques and now these early techniques have modernized via biomedical engineering.

Since technology has such an impact on medical care, engineering professions have become intimately involved in many medical ventures (Schwan, 1984). As a result, the discipline of biomedical engineering has emerged as an integrated medium for two dynamic professions - medicine \& engineering and ever since it has been assisting in the struggle against illness and disease by providing tools such as biosensors, biomaterials, image processing and artificial intelligence that the health care professionals can use for their research work, diagnosis and treatment (Singh, 2009). Thus, the biomedical engineers relatively serve as a new member of the health care team that tends to seek new solutions for difficult problems confronting our modern society. This is one of the emerging fields that seeks to close the gap between the medical and engineering fields. Biomedical engineering is a multidisciplinary branch of engineering which deals with the medical instrument and analysis of diseases through instruments or professionals. Biomedical engineering is a growing discipline of engineering due to the available research scope (Khandpur, 1994). The principle of engineering is combined with medical science aiming to the streamline of the health care services throughout the globe. This is a discipline of engineering which closes the gap between engineering and medicine and combining the concept of both the computer-based algorithm, construct the biomedical instrument to solve the health care treatment problems (Anandanatarajan, 2011).

The scopes in biomedical engineering in India and across the globe are numerous. Now there are several types of biomedical engineering such as genetic, tissue, clinical and chemical, neural and stem cell engineering for healthcare (Rao, \& Guha, 2001). Many magnetic and electronic equipment and methods are used for bioengineering like Magnetic Resonance Imaging (MRI) scans, Electroencephalography (EEG), Computed Tomography (CT) scans (Trumbower and Enderle, 2003). Apart from this ultrasound and regenerative medicine and stem cell cultures, preparation of artificial cells and organs such as the urinary bladder, liver cells, pancreas and fibroblasts cells of foreskin and others. In fact, any patient under a doctor is observed using biomedical instruments. Biomedical Instruments also play a vital role in the diagnosis of minor diseases as well as the major ones like tumor, cancer etc (Tagawa et al., 2011). Biomedical engineering thus is a blooming discipline in India.

The present paper is divided into four (4) parts, in the first part we discuss the current scenario of biomedical engineering in India; secondly we will discuss biomedical engineering courses at different educational levels, then the future scope of biomedical engineering from the job perspective and at last conclusion of biomedical engineering.

\section{THE AIM OF THE STUDY}

The present study is aimed at the overview of Biomedical Engineering in India and its education at different levels (diploma, undergraduate engineering, postgraduate engineering level, doctoral and postdoctoral level).

The authors of the manuscript have outlined the three major objectives in this paper: 1) to give the complete overview of biomedical engineering in terms of education and research;2) to give a comparative view of the job perspective related to the biomedical engineering field in India; 3) to give a brief insight into the future scopes of biomedical engineering in India.

\section{THEORETICAL FRAMEWORK AND RESEARCH METHODS}

The theoretical framework of the present manuscript consists of the recent data on Biomedical Engineering education in India which were recorded from the different institutional 
sciendo Порівняльна професійна педагогіка 9(4)/2019 Comparative Professional Pedagogy 9(4)/2019

websites. The Biomedical Engineering branch at Banaras Hindu University [Now part of Indian Institute of Technology (BHU), Varanasi, Uttar Pradesh, India] was established by the UGC during the Fifth Five Year Plan in the year 1978. This is the first independent department or school dedicated to the Biomedical Engineering in India. Banaras Hindu University is quite fortunate to have both the Institute of Technology and the Institute of Medical Sciences on the same campus (School of Biomedical Engineering, 2019).

India has a huge number of technical educational institutes which can be subcategorized into three categories named as polytechnics, technical institutes and technical universities which offers diploma in 60 major disciplines, an undergraduate degree in 45 different engineering disciplines and post-graduate degree is offered in almost 200 engineering specializations (Khare et al., 2015). Doctoral and Postdoctoral degree courses related to biomedical engineering are offered by the premium Indian institutes including technical and medical institutes. Indian Institute of Sciences, India Institute of Technology, All India Institute of Medical Science and National Institute of Technology are some of the top institutes that offer specialized courses in biomedical engineering.

Due to the rapid growth of technology and the improvement of medical facilities across the country which includes the establishment of specialized hospitals, there is a huge demand of professional biomedical engineers to handle the sophisticated medical equipment.

The diploma courses are of six semesters or 3 years, undergraduate courses (B.E or B.Tech) is of 8 semesters or 4 years, undergraduate degree courses are of six semesters or 3 years, dual degree courses (B.Tech with M.Tech or MBA)are of ten semesters or 5 years (Khare et al., 2014).The duration of doctoral degree courses is normally from 3 to 4 years depending upon the type of the course but it can also be extended up to 6 or 7 years according to the need for research work or clinical deliveries. Doctoral students have 2 -semester courses which include three to six subjects according to the requirement of the research topic. The duration of post doctoral program is 2 years, but it can be extended up to 3 years according to the requirement of the research work (Khare et al., 2016; Bajpai and Akhtar, 2017).

Only a few polytechnics offer diploma courses in biomedical engineering in India. Government Polytechnic for Girls, Gujarat; AWH Polytechnic College, Kerala; Parul University Gujarat; are some of the major institutes which offer diploma courses in biomedical engineering.The first-year course structure of biomedical engineering is similar to the other running specializations of diploma courses in which subjects related to basic Mathematics, English foundation of Information Technology, basic chemistry and physics, digital electronics are introduced to the students. Specialized courses of human anatomy and physiology are also in the first-year curriculum. In the sophomore, the core subjects related to biomedical engineering are offered to the students which include medical electronics, medical sensors, data communication networking, hospital management, diagnostic medical instrumentation, analytical and optical instrumentation, microprocessor, rehabilitation engineering, medical imaging techniques, critical care instruments. In the final year of diploma, the subjects which the students are offered include telemedical instrumentation, ophthalmic instrumentation, virtual medical instrumentation, biomaterial and implants.

There are around 10 core subjects at the undergraduate level (B.E or B.Tech) and out of which 4 to 6 are elective subjects and a couple of courses to focus on the interdisciplinary courses (Bajpai et al., 2016). In the 4-year curriculum of education in biomedical engineering, each semester includes 5 to 6 theory subjects and 3 to 4 lab subjects (Bajpai et al., 2016). The first-year curriculum of biomedical engineering is similar to the other 
engineering discipline which is more focused on the introduction of each engineering discipline (Bajpai, \& Kidwai, 2017). From the sophomore onward, the courses involved in the biomedical engineering includes the major core subjects like biomechanics, bioinstrumentation, medical imaging technology, biosensors, bio-signal analysis, circuit theory, hospital management, control system, molecular biology, biomaterial etc. Biomedical Instrumentation is offered as an open elective subject for the other engineering disciplines whereas it is a core subject for the pre-final and final year biomedical engineering students.

At the Post graduation level, biomedical engineering is offered in the name of the biomedical instrument or biomedical instrumentation or medical imaging. There are other advanced subjects of instrumentations, sensors and image technology with a couple of subjects related to hospital management due to the awareness of health issues among the population. There is a rapid development of health care services with modern specializations in India. Moreover, medical services now are more dependent on the response of the medical instrument such as diagnosis, therapy, surgery, pathology etc.

\section{RESULTS}

The advancements in the technology and the applications of medical instruments will tend the biomedical engineers to see rapid employment growth. A wide range of job opportunities has been offered to biomedical engineers (Griffith \& Grodzinsky, 2001). The nature of work in this field varies depending on area one is specialized in as a biomedical engineer. Biomedical engineering can be considered as one of the blooming disciplines of engineering not only in India but worldwide which creates the best job prospect for students. There are a variety of medical equipment, machines and medical devices that are used in medical research, therapy and diagnose by biomedical engineers to improve health and save lives. Some of which are the laser systems used in corrective eye surgery, systems for analyzing blood, suction devices to suck up secretions, ECG machines to record and detect electrical activity of the heart over a period of time etc are prominent to the society and thus it's the duty of a biomedical engineers to design, install, maintain and repair them (Vishwa et al., 2011). Some popular specialization and jobs in biomedical engineering are discussed below.

Clinical engineering is the area of specializations in biomedical engineering which is focused on the applications of methodologies and theory of the biomedical engineering field to improve the quality of health services (Castañeda, \& Judd, 2019). Clinical engineers are those who find the uses and the methods of utilization of medical products in hospitals and other healthcare facilities. Clinical engineering supports the use of biomedical technologies in the hospital organizations and medical professionals with proper skills in order to make concessions between clinical efficiency, patient and operator's safety, innovation and care quality, management and equipment costs.

Clinical engineers also work alongside nurses, physicians, therapists, technicians and other medical personnel to help them in implementing and operating the medical equipment and technologies. This field deals with the body structure, function and motion of the mechanical aspects of our biological systems. The designing and developing of the products that aid with motion within the body is done by the engineers who are specialized in biomechanics. Some of the common aspects in which a biomechanic engineer deals are joint replacements, transplantation of artificial heart valves that assist with the flow of blood and motor functions respectively. Biomechanics also deals with the study of the principles of physical mechanics combined with the knowledge of biology. 
sciendo Порівняльна професійна педагогіка 9(4)/2019 Comparative Professional Pedagogy 9(4)/2019

Genetic engineering is an alteration of the genes of an organism to modify its features and to improve its quality. Genetic engineering is also the modification of an organism's phenotype by manipulating its genetic material (Naldini, 2019). Biomedical professionals who are specialized in genetic engineering, work on a microscopic level to find out the solutions for the problems such as insulin production and in understanding the progression of diseases and developing several ways to treat it or halt it. Gene therapy is the genetic engineering of humans which is done by replacing defective genes with effective ones. This specialization in biomedical engineering is also called recombinant DNA technology.

Medical imaging is also a specialization in biomedical engineering which deals with the process and techniques of creating visual representations of the interior of a body for clinical analysis and medical examinations, as well as for the visual representation of the function of some organs or tissues in the human body(Bonmati et al., 2018).Biomedical engineers who are specialized or work in the medical imaging field can develop and design medical devices that will further enable healthcare professionals to see inside the human body.

Now, a separate paper for Biomedical Engineering is introduced from GATE (Graduate Aptitude Test in Engineering) 2020 in India. The score of GATE is used for applying for postgraduate and doctoral studies. Its scorecard is used by the companies to shortlist the candidates for the various job vacancies.

\section{CONCLUSIONS}

Biomedical engineering is a vast and diverse field which incorporates and includes the knowledge of every engineering field, providing solutions to medical problems using technology. It brings together the applications of the medical sector along with the engineering skills for further advancements in the medical field. The biomedical engineers can specifically work in biomedical engineering sectors, healthcare centers and organizations and even at academic places. Bioengineers also works with the professionals in the health care system with the nurses, doctors, therapist, physicians, technicians, scientists, medical researchers and manufacturers to address a wide range of injuries and physical disabilities.

There is a significant growth of engineering in India at each engineering discipline. Further the biomedical engineers can contribute to the designing of systems that can monitor a patient's health, create biosensors for the measuring of $\mathrm{pH}$ in the blood stream, design various units and clinical labs within hospitals using engineering technologies so that better aids can be provided to the patients etc. Apart from this employment in the biomedical field tend to increase by $7 \%$ from the year 2016 to 2026 because of the increasing possibilities of technology and the increasing applications of bio-engineered instruments in medical science. Biomedical engineers usually work in research fields for the development of several instruments and work for its quality assurance. The engineers further work on designing of the electrical circuits and software to run several types of medical equipment used in pathologies or hospitals. In addition to this, biomedical engineers can also design and make artificial body parts such as knee and hip joints as per the requirement of the patient.

The government of India should take initiatives of including biomedical engineering courses along with the MBBS course which will further help in the collaboration of biomedical engineering with the medical field. For the hospitals to provide advanced facilities to the patients the modern bio-engineered instruments have become a necessity in their departments and India being one of the largest manufacturers in the global industry, imports most of the bio-engineered instruments from other countries on high amounts. This matter should be looked into by the government of India to solve the crisis of bioengineered instruments and ensure the manufacturing of the instruments required and thus providing employment to quite a number of bioengineers in India. 
sciendo Порівняльна професійна педагогіка 9(4)/2019 Comparative Professional Pedagogy 9(4)/2019

\section{ACKNOWLEDGMENTS}

We would also like to extend our thanks to Integral University, Lucknow, Uttar Pradesh, India for quick and crisp review of the manuscript (MCN No-IU/R\&D/2019MCN000696) and providing needful suggestions.

\section{REFERENCES}

1. Anandanatarajan, R. (2011). Biomedical instrumentation and measurements. PHI Learning Pvt. Ltd.

2. Arntzen, A. A. B., \& Leguy, C. (2007). A model of knowledge sharing in biomedical engineering: Challenges and requirements.

3. Bajpai, Shrish, Siddiqui Sajida Asif, and Syed Adnan Akhtar (2016). Electromagnetic education in India. Comparative Professional Pedagogy, 6 (2), 60-66.

4. Bajpai, S., Khare, S., \& Yadav, R. (2016). Control education in India: present \& future. IFAC-PapersOnLine, 49 (1), 813-818.

5. Bajpai, S., \& Akhtar, S. (2017). Industrial engineering education in India. Comparative Professional Pedagogy, 7 (3), 84-92.

6. Bajpai, S., \& Kidwai, R. (2017). Renewable energy education in India. Comparative Professional Pedagogy, 7 (4), 103-113.

7. Bath, K., Aggarwal, S., \& Sharma, V. (2019). Sushruta: Father of plastic surgery in Benares. Journal of Medical Biography, 27 (1), 2-3.

8. Bonmati, E., Hu, Y., Villarini, B., Rodell, R., Martin, P., Han, L., ... \& Barratt, D. C. (2018). Error metrics for estimating the accuracy of needle/instrument placement during transperineal magnetic resonance/ultrasound-guided prostate interventions. Medical Physics, 45 (4), 1408-1414.

9. Castañeda, M., \& Judd, T. (2019). Global Clinical Engineering Innovation, Overview and New Perspectives. In World Congress on Medical Physics and Biomedical Engineering 2018 (pp. 827-831). Singapore: Springer.

10. Dixit, S., Hazarika, M., \& Davim, P. (2017). A brief history of mechanical engineering. New York, NY: Springer

11. Gharge, N. P., \& Naik, R. (2019). The concept of Leena Dosha wsr to latent phase of disease. Journal of Ayurveda and Integrated Medical Sciences, 4 (3), 69-72.

12. Gramatikov, B. I. (2014). Modern technologies for retinal scanning and imaging: an introduction for the biomedical engineer. Biomedical Engineering Online, 13 (1), 52.

13. Griffith, L. G., \& Grodzinsky, A. J. (2001). Advances in biomedical engineering. Jama, 285 (5), 556-561.

14. Khandpur, R. S. (1994). Handbook of biomedical instrumentation. Tata McGraw-Hill Education.

15. Khare, S., Bajpai, S., \& Bharati, K. (2015). Production engineering education in India. Management and Production Engineering Review, 6 (1), 21-25.

16. Khare, S., Chatterjee, A., Bajpai, S., \& Bharati, K. (2016). Manufacturing engineering education in India. Management and Production Engineering Review, 7 (1), 40-44.

17. Khare, S., Chowdhry, S., \& Bajpai, S. (2014). Control engineering education in India. Proceedings of Power, Control and Embedded Systems (ICPCES) International Conference. IEEE.

18. Mukhopadhyay, A. K. (2016). Dermatology in India and Indian dermatology: A Medico-historical perspective. Indian Dermatology Online Journal, 7 (4), 235.

19. Naldini, L. (2019). Genetic engineering of hematopoiesis: current stage of clinical translation and future perspectives. EMBO molecular medicine, 11(3). 
20. Padmanabhan, T., \& Padmanabhan, V. (2019). The Healing Art and Its Science. In The Dawn of Science (pp. 43-51). Cham: Springer.

21. Ovallath, S., \& Deepa, P. (2013). The history of parkinsonism: descriptions in ancient Indian medical literature. Movement Disorders, 28 (5), 566-568.

22. Rao, C. R., \& Guha, S. K. (2001). Principles of Medical Electronics and Biomedical Instrumentation. Universities press.

23. School of Biomedical Engineering, Indian Institute of Technology (Banaras Hindu University) Varanasi. (2019). Syallbus of different degree programs. Retrieved from https://www.iitbhu.ac.in/dept/bme.

24. Schwan, H. P. (1984). The development of biomedical engineering: Historical comments and personal observations. IEEE Transactions on Biomedical Engineering, (12), 730-736.

25. Singh, K. (2009). Biomedical engineering education prospects in India. In 13th International Conference on Biomedical Engineering (pp. 2164-2166). Springer, Berlin, Heidelberg. CRC press.

26. Tagawa, T., Tamura, T., \& Oberg, P. A. (2011). Biomedical sensors and instruments.

27. Trumbower, R. D., \& Enderle, J. D. (2003). Virtual instruments in undergraduate biomedical engineering laboratories. IEEE engineering in medicine and biology magazine, 22 (4), 101-110.

28. Vishwa, A., Lal, M. K., Dixit, S., \& Vardwaj, P. (2011). Clasification of arrhythmic ECG data using machine learning techniques. IJIMAI, 1 (4), 67-70. 